\title{
DEM based morphotectonical analysis of the Kisgyőr Basin (Bükk Mts - Hungary)
}

\author{
Péter PECSMÁNY1*, András HEGEDÜS² and János VÁGÓ
}

\begin{abstract}
Authors' affiliations and addresses: ${ }^{1}$ University of Miskolc Institute of Geography and Geoinformatics, Hungary, 3515 Miskolc Egyetemváros

e-mail: ecopeter@uni-miskolc.hu

${ }^{2}$ University of Miskolc Institute of Geography and Geoinformatics, Hungary, 3515 Miskolc Egyetemváros

e-mail: ecoeged@uni-miskolc.hu
\end{abstract}

${ }^{3}$ University of Miskolc Institute of Geography and Geoinformatics, Hungary, 3515 Miskolc Egyetemváros

e-mail: ecovago@uni-miskolc.hu

\section{*Correspondence:}

University of Miskolc Institute of Geography and Geoinformatics, Hungary, 3515 Miskolc Egyetemváros

tel.: +36 49/565-111 1393

e-mail: ecopeter@uni-miskolc.hu

\section{Acknowledgement:}

The described article/presentation/study was carried out as part of the EFOP-3.6.1-16-201600011 "Younger and Renewing University Innovative Knowledge City - institutional development of the University of Miskolc aiming at intelligent specialisation" project implemented in the framework of the Szechenyi 2020 program. The realisation of this project is supported by the European Union, co-financed by the European Social Fund

How to cite this article:

Pecsmány, P., Hegedűs, A. and Vágó, J. (2021).

DEM based morphotectonical analysis of the

Kisgyör Basin (Bükk Mts - Hungary). Acta

Montanistica Slovaca, Volume 26 (2), 364-374

DOI:

https://doi.org/10.46544/AMS.v26i2.14

\begin{abstract}
The south-eastern part of the Bükk Mountains and the eastern side of its foothill, the Bükkalja are among the less explored regions of Hungary. Based on our examinations on the field, we found that the asymmetrical valley sections, the tipped escarpments and the formation of the Kisgyör Basin cannot be explained by the differences in the rock quality. The asymmetrical shape of these landforms and the stream captures identified in the research area indicate significant structural geological changes. In our work, we proved the asymmetry in the topography by performing swath profile analysis, and we also examined the elevation data of the areas covered by the welded ignimbrites of the Tar Dacite Tuff Formation. The results confirmed our field observations. We found that, contrary to the results of previous research, the geological structural processes played a fundamental role in the formation of the Kisgyőr Basin and its surroundings.
\end{abstract}

\section{Keywords}

DEM, Geomorphometry, Swath profile analysis, Structural

morphology, Basin analysis, Bükk Mts., Bükkalja 


\section{Introduction}

The Kisgyör Basin is located in the south-eastern foreland of the Bükk Mountains. During our field investigations, we found that in the surroundings of this basin, many valleys are asymmetrical in nature, and stream captures, wind gaps were also identified in the study area. In previous researches (Less et al., 2005), the development of the basin was explained by fluvial erosion directed by differences in rock resistance to the erosion, although the latter geological mapping campaigns indicated faults in the area (Radócz, 1989; Lukács et al., 2010). Based on our field surveys, we assumed that the valley asymmetry and the presence of such landforms cannot be explained simply by differences in rock quality characterised by diverse petrological properties, and we hypothesised that structural geological processes also played a role in the surface development of the area.

The aim of our work was to prove this hypothesis. For this purpose, we performed swath profile analysis on a digital elevation model. We also analysed the elevation of the hilltops covered by the rocks of the Tar Dacite Tuff Formation, which rock type has a decisive role in the landscape evolution of the area. Borehole data was also examined to investigate tectonic movements.

\section{Materials and Methods}

\section{Location}

Based on the official Hungarian landscape classification, the research area $\left(291 \mathrm{~km}^{2}\right)$ is situated in the south-eastern part of the Bükk Region, microregion group of the North-Hungarian Mountain Range region (Csorba et al., 2018). The north-western part of the area $\left(65 \mathrm{~km}^{2}\right)$ belongs to the mountainous microregion of South-Eastern Bükk (Hevesi, 2003), the south-eastern hills $\left(226 \mathrm{~km}^{2}\right)$ are located on the eastern part of the Bükkalja foothills microregion (Csorba et al., 2018). The boundary of the microregions can be drawn along the fault lines between the Mesozoic and Cenozoic rock formations (Dobos, 2000). Two submontane basins can be found at this boundary with different geological features and geomorphological landscapes, the Kács Basin and the Kisgyőr Basin (Hevesi, 2003; Pecsmány, 2017). In our research, we focused mainly on the Kisgyőr Basin and its southern surroundings (Fig. 1).

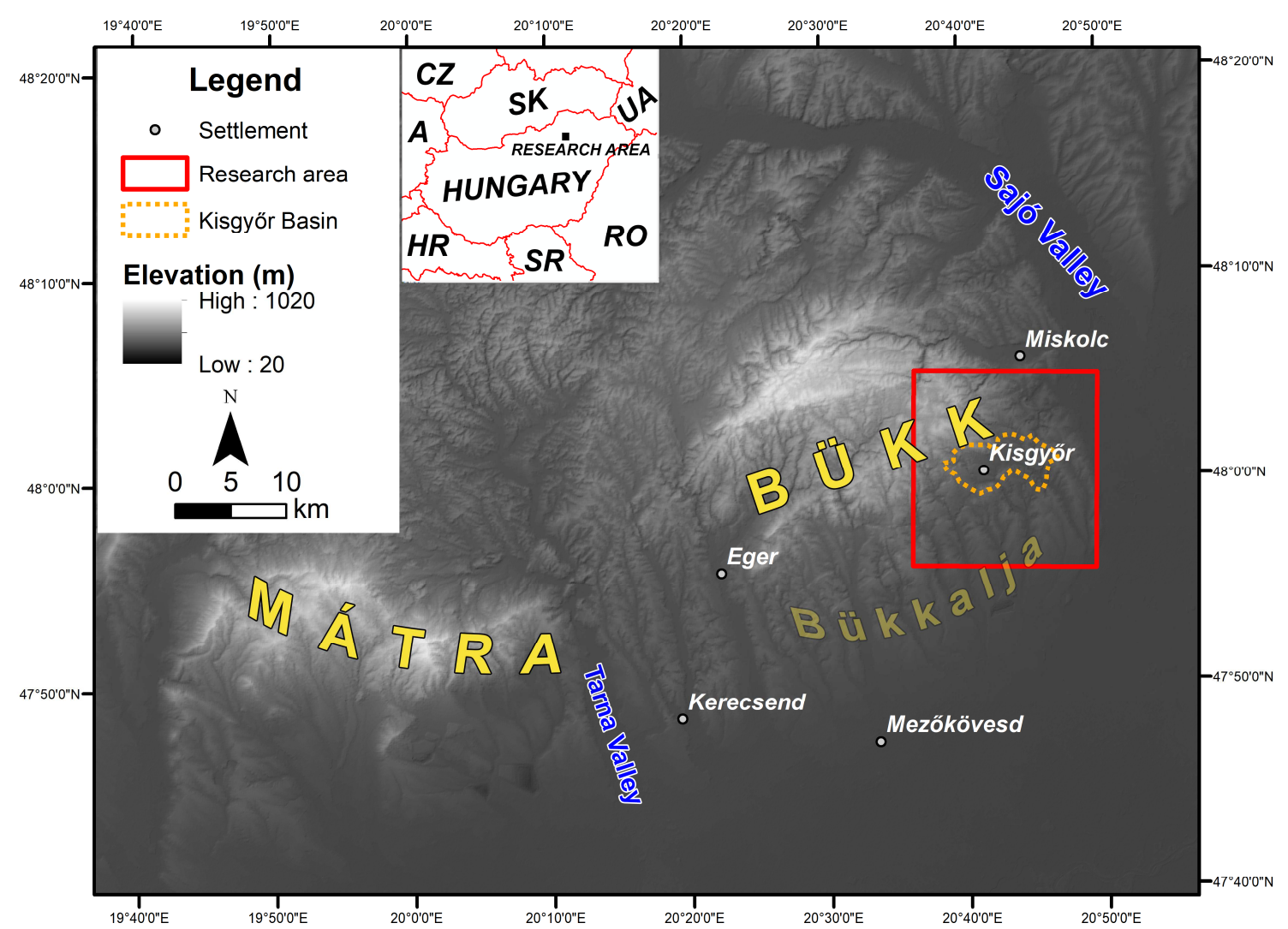

Fig. 1. Location and topography of the research area (source: EUdem).

\section{Geology and geomorphology of the research area}

The geomorphology (Hevesi, 1978, 1986, 2002a, 2002b; Hevesi \& Záhorszki, 2000) and the geological characteristics of the Southern-Bükk (Csontos, 1988, 1999; Pentelényi, 2002, 2005; Less et al., 2005; Németh, 
2005) and the Bükkalja (Dobos, 2002; Less et al., 2005; Vágó, 2012; Vágó \& Hegedüs, 2011; Petrik, 2016; Pecsmány, 2017) are well known. However, the eastern side of Bükkalja has not been examined yet in detail from a geomorphological and geological point of view.

This mountainous region is mostly composed of strongly karstized Triassic limestones (Berva Limestone Formation, Bükkfennsík Limestone Formation) with dolines, sinkholes, cave springs and less karstized cherty limestone (Felsőtárkány Limestone Formation) without dolines and caves (Fig. 2) (Hevesi \& Záhorszki, 2000; Less et al., 2005). These Mesozoic rocks are covered by Cenozoic deposits in the area of the Bükkalja due to vertical fault displacements (Less et al., 2005; Németh, 2005; Petrik, 2016).

There are Cenozoic sediments on the surface of the foothills: Eocene-Oligocene limestone and calcareous marl (Szépvölgy Limestone Formation), clay and clayey marl silt (Buda Marl Formation, Kiscell Clay Formation) in the north (Less et al., 2005); variable-stability Miocene pyroclastics (sometimes ignimbrite) produced by the periodic volcanic activity (Lukács et al., 2018) (Gyulakeszi Rhyolite Tuff Formation, Tar Dacite Tuff Formation, Harsány Rhyolite Tuff Formation) in the middle (Less et al., 2005; Lukács et al., 2010); sedimentary rocks of former Lake Pannonian (Egyházasgerge Formation, Sajóvölgy Formation, Zagyva Sand Formation, Edelény Variegated Clay Formation, Bükkalja Lignit Formation, Nagyalföld Variegated Clay Formation) in the south (Less et al., 2005) (Fig. 2). Due to the differential weathering of volcanic tuffs, there is a sandy, gravelly colluvium (grézes litées) on the gentle slopes (Pinczés et al., 1993), which was often redeposited by fluvial erosion and downhill mass movements. South of the tuff strip, with a gradual decrease in clay content, loess, resedimented loess, sand, gravel are common (Less et al., 2005).
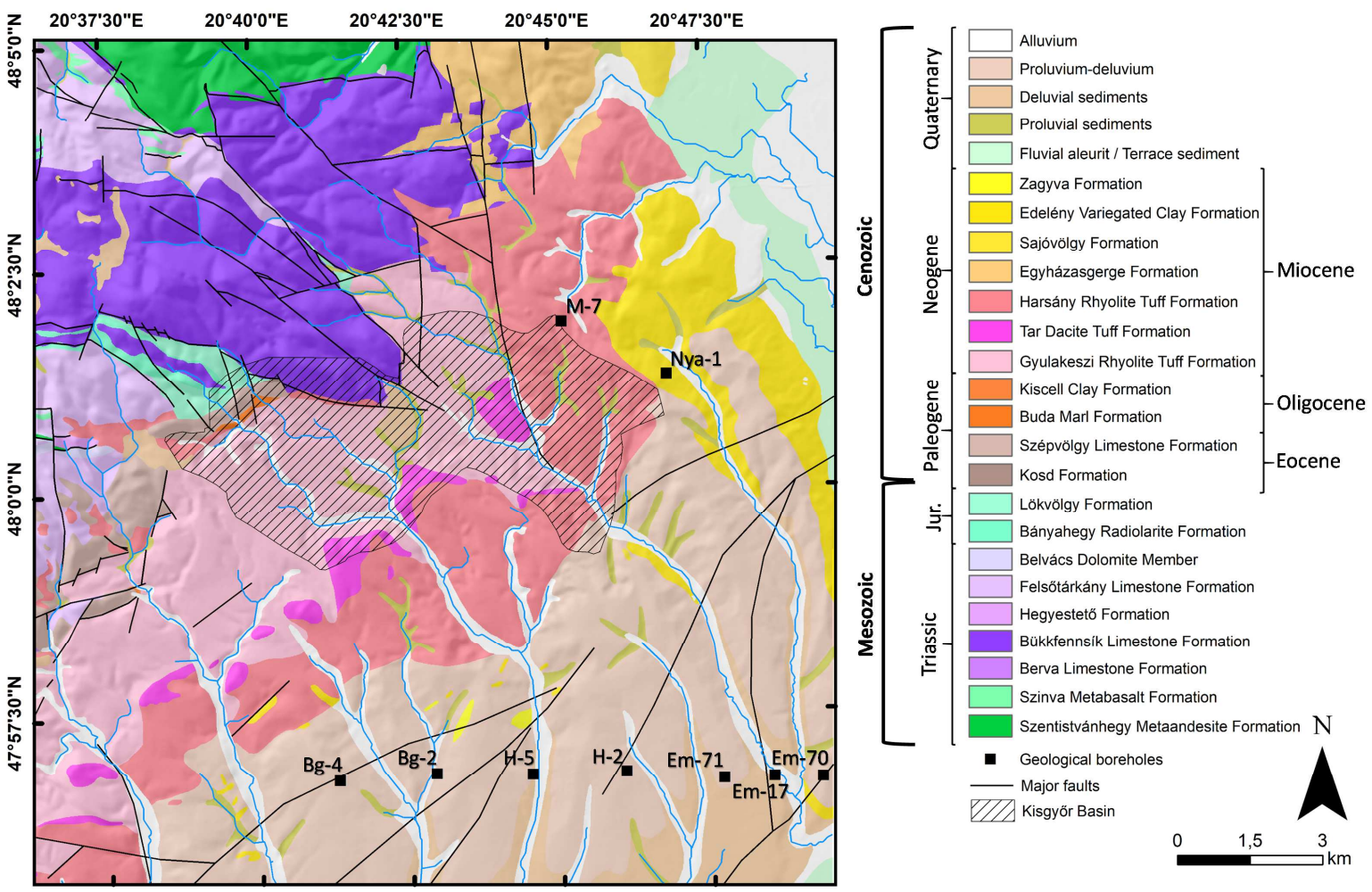

Fig. 2. Geological map of the research area (Gyalog \& Síkhegyi, 2005), major faults (Less et al., 2005; Németh, 2005; Petrik, 2016) and location of examined boreholes.

\section{Swath profile analysis}

Swath profile analysis is statistically more reliable, improved version of cross-section analysis, which is a traditional method in geomorphological studies (Fielding, 1996; Kühni \& Pfiffner, 2001; Korup et al., 2005; Stolar et al., 2007; Robl et al., 2008; Telbisz, 2011; Telbisz et al., 2012, 2013). The method has already been successfully applied in structural morphological research (Kovács, 2013). The breakages appearing in the diagrams of cross-sections and swath profiles may indicate structural causes and neotectonic processes (Keller \& Pinter, 1996; Burnak \& Anderson, 2001).

The swath method horizontally expands the cross-section line into a rectangular swath. Based on their distance from the baseline of the swath, the pixels in the swath are grouped, and their statistical parameters (minimum, mean, maximum, quantiles) are calculated (Telbisz et al., 2011, 2013).

In our study, two swath profiles were made at all locations. One profile was made to analyse the terrain; the other was made for the remnant surfaces delineated by the method of Telbisz (2009). (The method of Telbisz (2009) is based on the determination of local maximum values of the digital terrain model.) Both profiles, since 
they were made in the same swath, were plotted on one diagram. In the case of the terrain, the minimum, maximum, and mean values were plotted by lines, while the remnant surfaces were visualised by dots (maximum values) (Fig. 3).

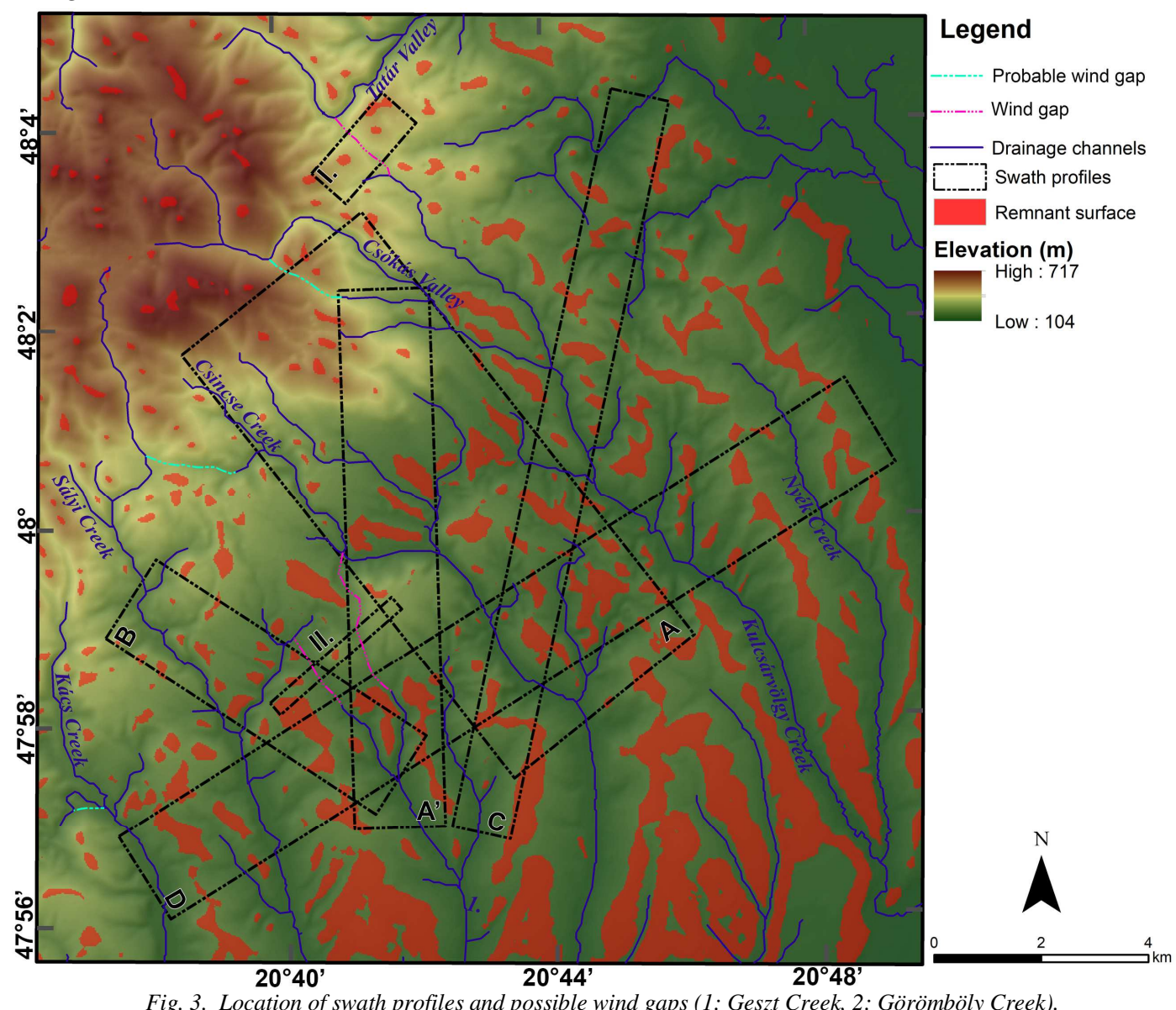

Results

\section{Result of swath profile analysis}

In the Southern-Bükk area, the maximum elevation values of the delineated remnant surfaces show that the karstic peneplain gradually steps off towards the basin (Fig. 4). Based on the position of the remnant surfaces on the northern edge of the Kisgyör Basin, the fault(zone) that was already explored during structural geological research can be designated (Less et al., 2005; Németh, 2005). The remnants of the upper pediment framing the northern edge of the basin can be "connected" by a straight line to other upper pediment segments located to the south of the basin, with the same slope angle (Fig. 5).

In the southern part of the basin at the tilted escarpment, another level can be designated, which cannot be paralleled with the remnant surfaces of the northern side with the same slope angle. The southern edge of the basin is bordered by an asymmetrically tilted cuesta. This is confirmed by field observations and the swath profile analysis (Fig.4, Fig 5). Due to the tilted position of the cuesta, we assume that the southern edge of the basin was also appointed by a fault. The remnant surfaces inside the basin may also have tilted along faults (Fig. 5), as they can be connected by a straight line. The faults can be the synthetic faults of the main fault tilting the cuesta. These are inclined almost in the same direction as the main fault in the line of the cuesta.

The fault on the southern edge of the basin also causes the asymmetric nature of the Tarizsa Valley (Fig. 6). Less et al. (2005) assumed a fault north of this valley. However, based on the morphology of this area, the fault might be in the valley. It cannot be ruled out that these are two different faults; this could only be verified by geophysical measurements.

Based on field trips, the valleys south of the basin were perceived as asymmetric. To prove this, we prepared a SSW-NNE (Fig. 7) and a WSW-ENE (Fig. 8) swath profile.

In the case of the Sály Creek, the asymmetrical character is caused by a fault, which has already been confirmed by seismic cross-sections (Pecsmány \& Vágó, 2020).

Figures 7 and 8 show that the Csincse Creek, leaving the basin, runs in an asymmetric valley. On the profile "D", the asymmetrical nature is less visible in the maximum elevation values. This may also be due to the 
orientation of the swath profile section. Based on the average values and the position of the remnant surfaces, we can conclude a significant fault displacement in the case of Csincse and Geszt Creeks.

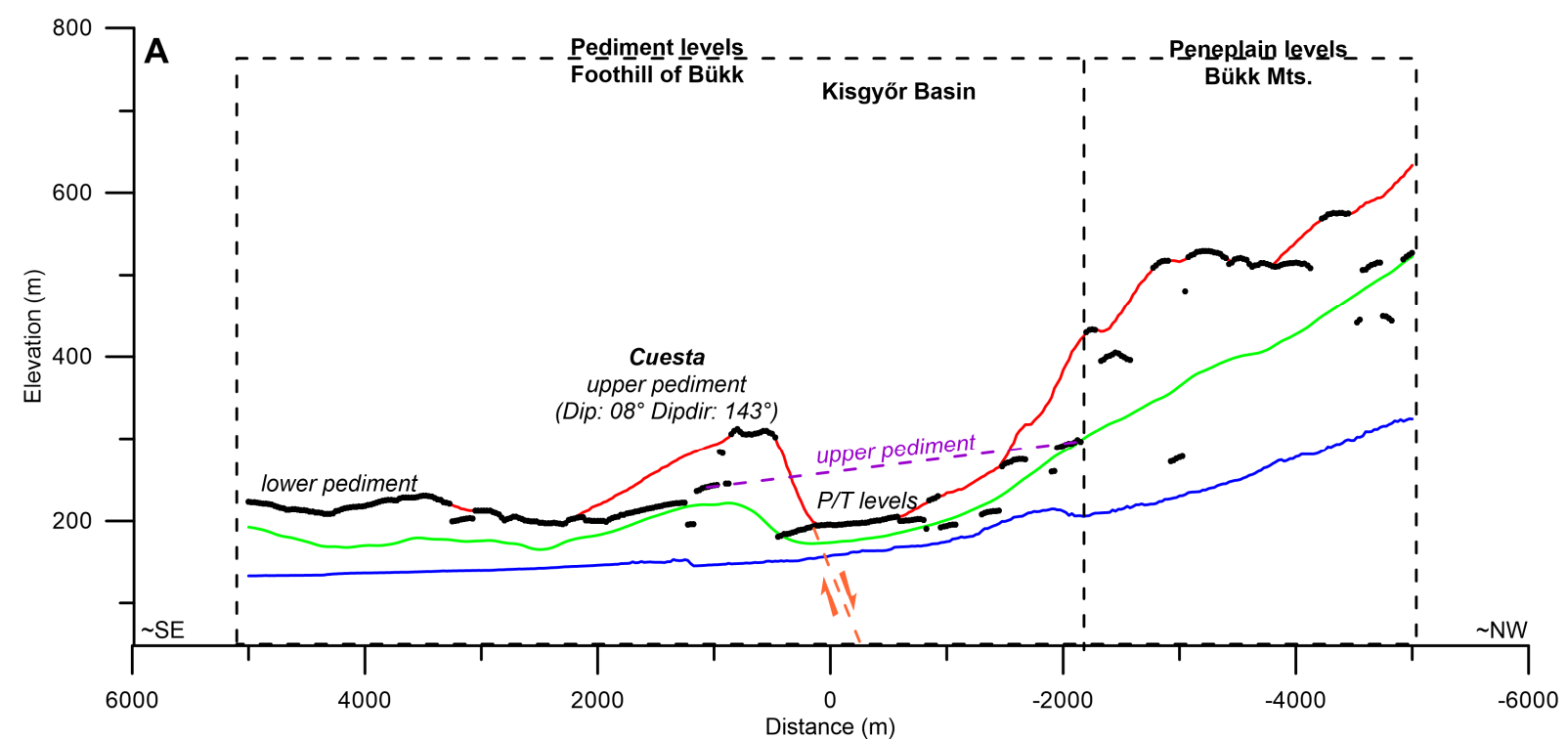

Fig. 4. Swath profile "A" (red: maximum elevation, green: mean elevation, blue: minimum elevation values, dots: elevation of hilltops delineated by the Telbisz (2009) method).

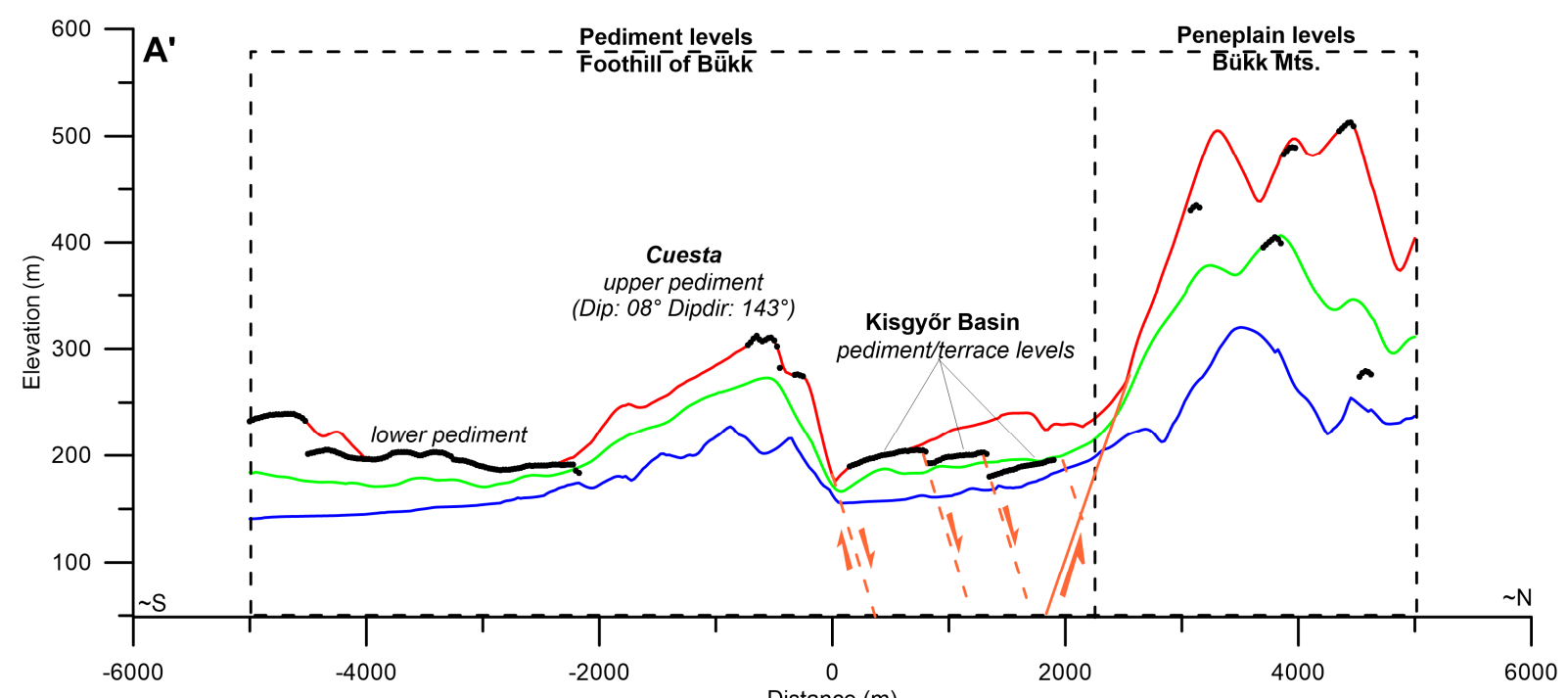

Fig. 5. Swath profile "A'" (red: maximum elevation, green: mean elevation, blue: minimum elevation values, dots: elevation of hilltops delineated by the Telbisz (2009) method).

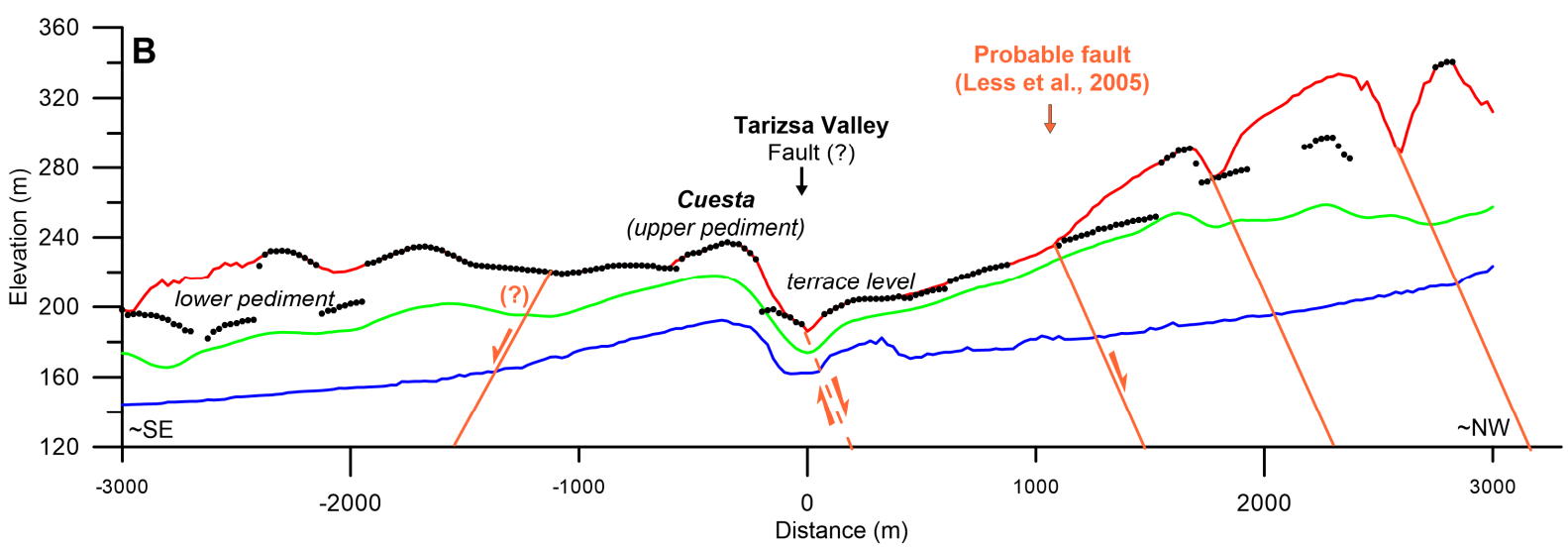

Fig. 6. Swath profile "B" (red: maximum elevation, green: mean elevation, blue: minimum elevation values, dots: elevation of hilltops delineated by the Telbisz, (2009) method). 


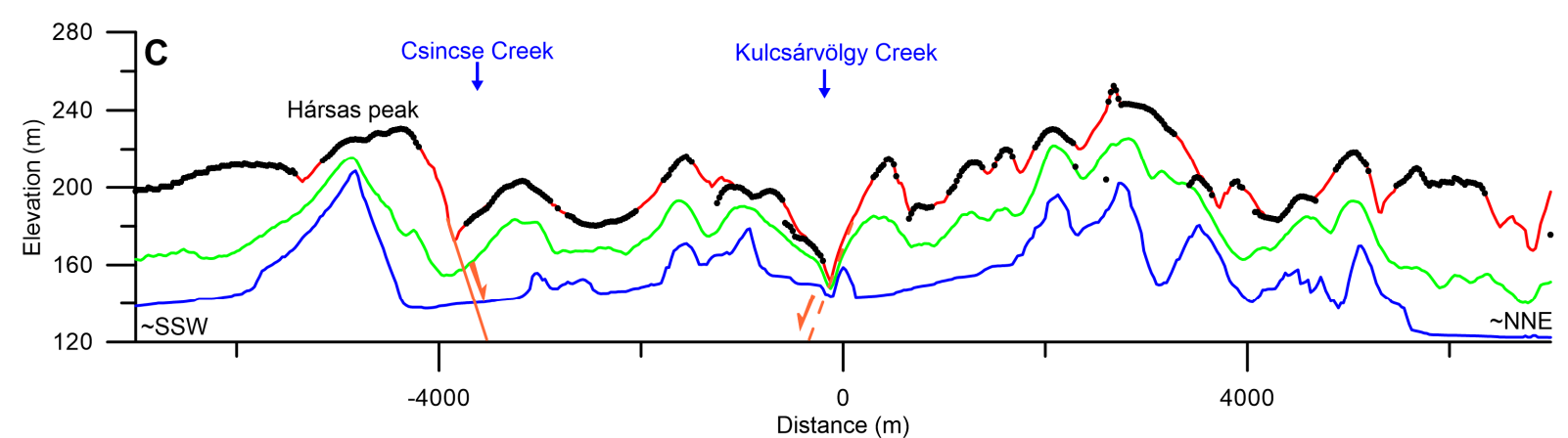

Fig. 7. Swath profile "C" (red: maximum elevation, green: mean elevation, blue: minimum elevation values, dots: elevation of hilltops delineated by the Telbisz (2009) method).

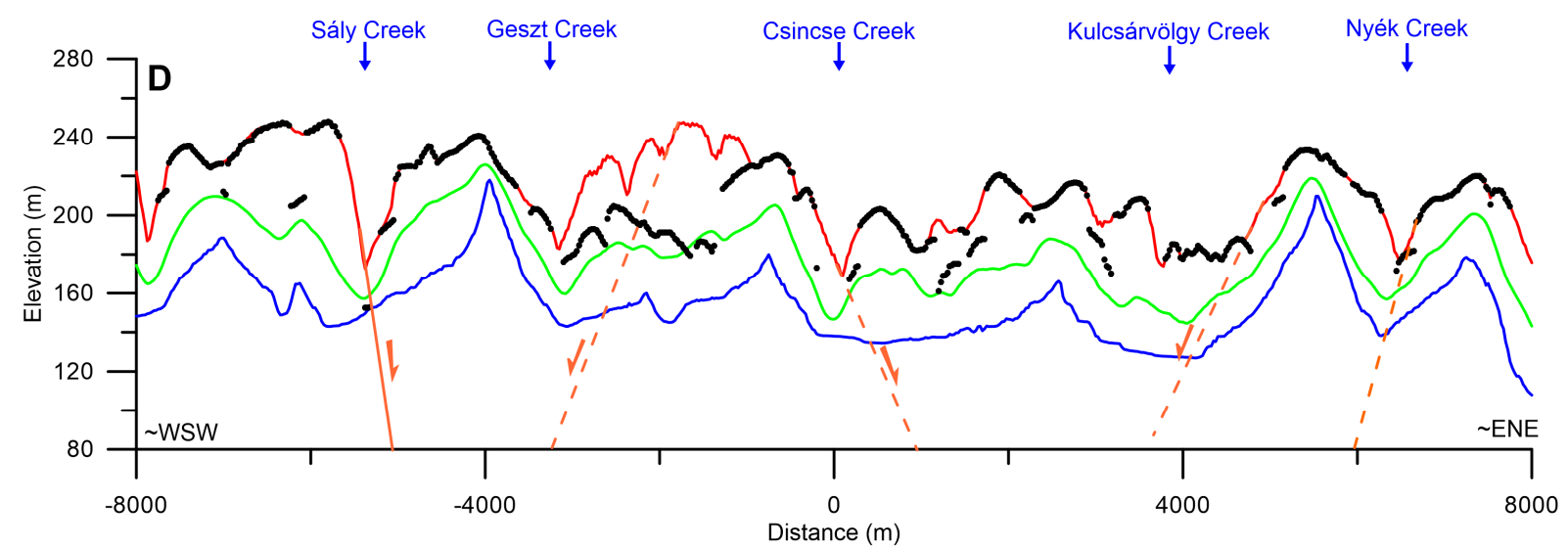

Fig. 8. Swath profile "D" (red: maximum elevation, green: mean elevation, blue: minimum elevation values, dots: elevation of hilltops delineated by the Telbisz (2009) method).

The Kulcsárvölgy Creek runs in a valley performed by a structural element in the Kisgyőr Basin (Németh, 2005; Less et al., 2005). In the basin, probably a fault causes the asymmetrical nature of the valley (Fig. 7). Since this asymmetrical shape is retained, leaving the basin, we conclude that the structural element continues towards the SE direction. The stream flows in the tuff strip and to the south of it in a structurally preformed valley (Fig. $8)$.

Based on field surveys and the analysis of the digital elevation model, we identified stream captures in the research area (Fig. 3). Swath profile analysis was performed in the abandoned valleys of these stream captures. As a result of this examination, morphological levels were identified in two wind gaps, which were identified as rock terraces (Fig. 9).

In the abandoned valley of the Tatár-árok (Szentlászló Valley) (Fig. 9, profile "I") a morphological level can be identified, at the same height on both valley sides (Fig. 9, profile "I"). This abandoned valley is structurally preformed (Németh, 2005). Previously prepared geomorphological maps indicate several sinkholes in the valley (Hevesi \& Záhorszki, 2000). It is probable that the Tatár-árok could originally run in the NW-SE direction towards the Kulcsárvölgy Creek. It probably belonged to the catchment area of the Kulcsárvölgy stream until the diversion. The cause of this capture was the lowering of the Sajó Valley and the rising of the Bükk Mountains, which caused intense headward erosion.

In the abandoned valley of the Csincse Creek (Fig. 9, profile "II"), a morphological level can be observed on the side of the Meleg Hill. On the side of Halomvár Hill, this level was destroyed by erosion. The stream capture was caused by a fault tilting the cuestas. In our previous research (Vágó, 2012), we observed a breakpoint on the longitudinal profile of Csincse Creek at the location of the stream capture; it also proves its existence.

In both cases, the relative height of the geomorphologic levels is 40-50 meters above the valley bottom. Based on the terrace morphological studies carried out in Bükkalja (Pinczés, 1957; Krolopp et al., 1989), these can be identified as remnants of the oldest terrace level (terrace level No. V), (Fig. 9).

The rectangular change of direction of the Csókás Valley in the northern part of the study area (Fig. 3) can also be interpreted as a stream capture. During our field trips, we identified several sinkholes in and around the wind gap, which show the former flow direction. Both the recent and former valleys of the Csókás Creek are structurally preformed (Fig. 2). The formation of the stream capture was probably caused by the downfaulting of the current valley of the Csókás Creek and the backward erosion of a side valley. 

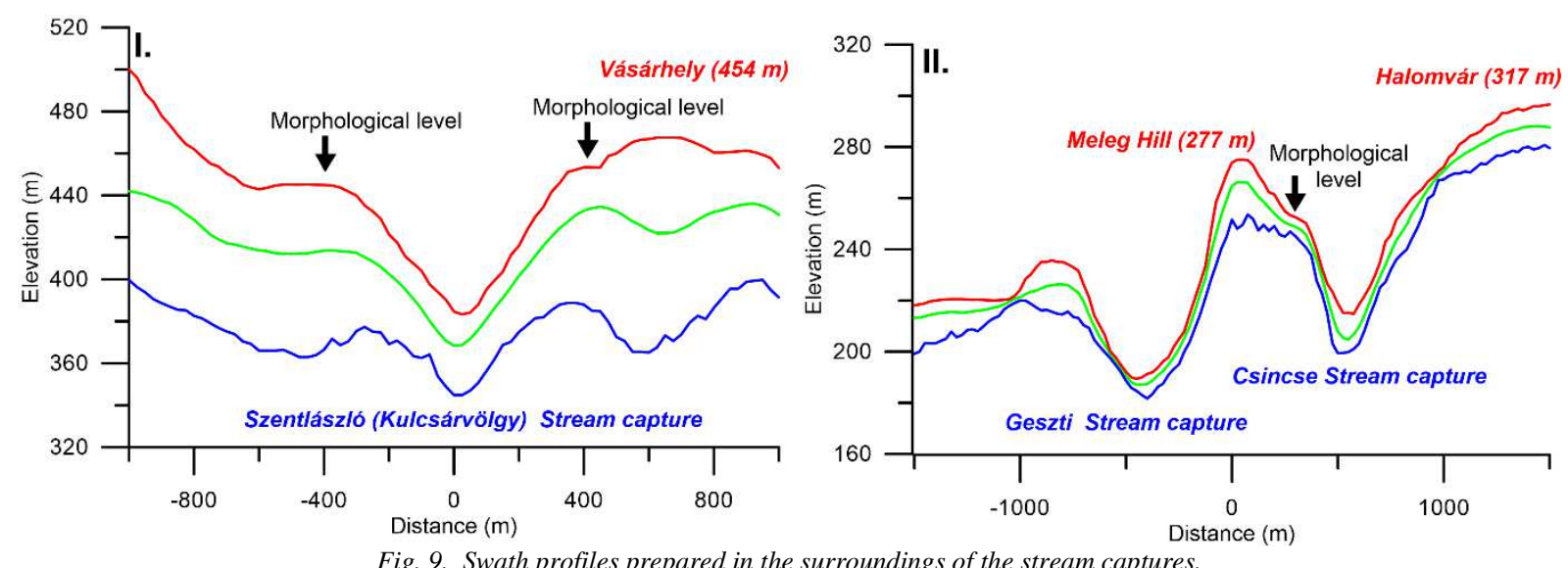

\section{Other methods to verify structural preformation}

Analysis of height conditions of Tar Dacite Tuff Formation by histogram. The histogram is the distribution of the elevation values of the digital elevation model. Based on the height distribution of the DEM, conclusions can be drawn regarding erosion surface development. By examining the elevation of each rock types, we can infer not only the erosional surface development but also structural processes in the case of rocks with the same properties (Zámolyi et al., 2010), since the different elevation of areas with the same lithological features may indicate structural movements.

We successfully applied the DEM based histogram analysis in our studies for the examination of Bükkalja's pediment levels (Vágó \& Hegedüs, 2011) and its basins (Pecsmány, 2017).

In this investigation, the DEM based histogram analysis was performed only for the area of the middlevolcanic complex (Tar Dacite Tuff Formation) because this formation is located in the NE-SW direction in one strip, and due to its petrological features (most of these rocks are welded ignimbrites) it is more resistant to erosion, and based on geological maps (Gyalog \& Síkhegyi, 2005) it covers the hilltops of the interfluves (Fig. $10)$.

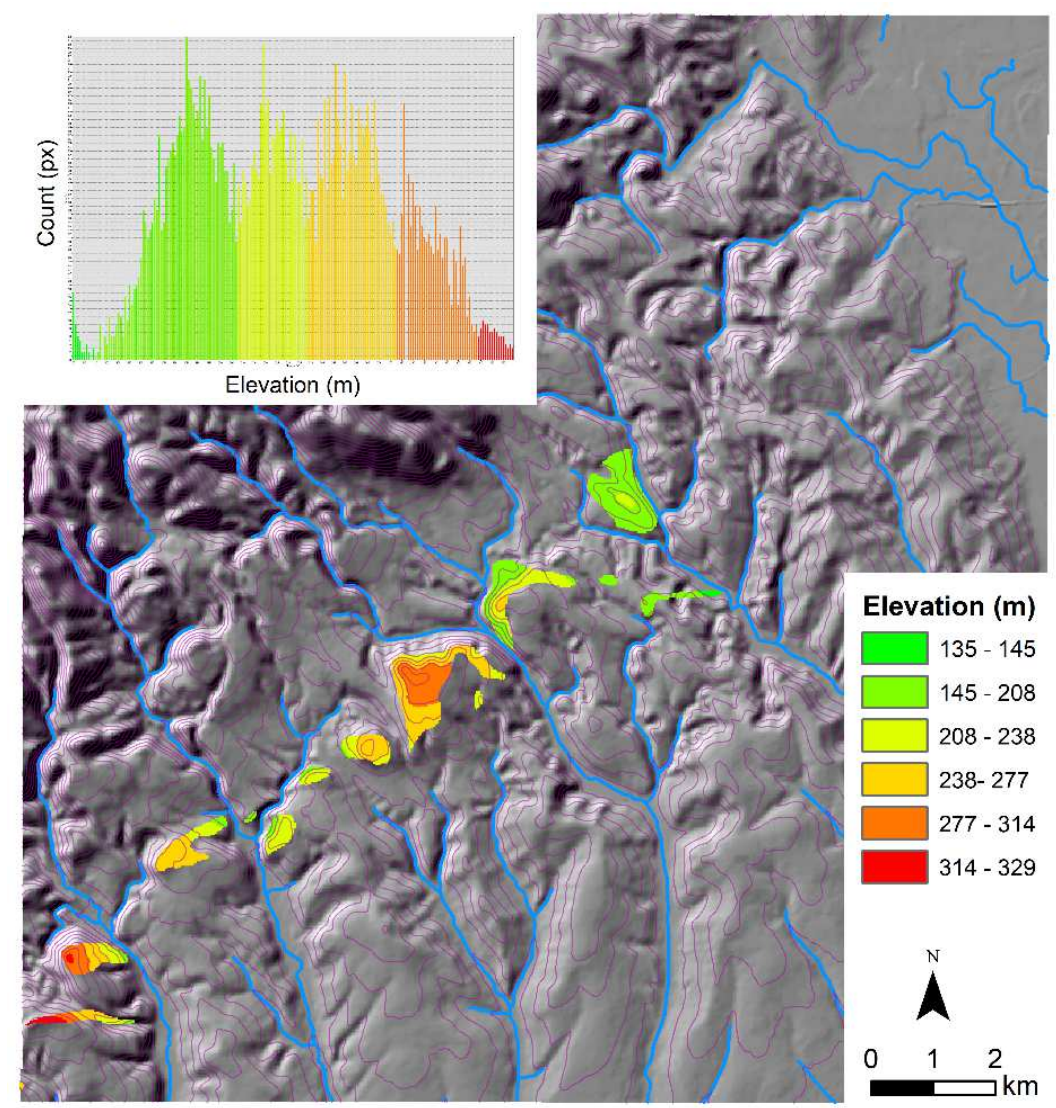

Fig. 10. Elevation of locations covered by Tar Dacite Tuff Formation. 
Analysing the histogram of the rock types, 6 elevation classes can be assigned. Several breakpoints can be observed on the histogram showing the elevation of locations covered by this lithological unit. Based on these breakpoints, we reclassified the DEM. It can be clearly seen (Fig. 10) that the ignimbrite patches on both sides of the main valleys are located at different elevations above sea level. As it is the same rock type, the asymmetric nature cannot be explained by denudation processes. This analysis also confirms our finding mentioned in the previous chapter that the main valleys running in NE - SW direction are structurally preformed.

Geological borehole analysis (correlation). We analysed borehole data to investigate the structural movements in the catchments of Nyék, Kulcsárvölgy, Csincse and Geszt Creeks (Fig.2, Fig. 11).

The valley of Nyék Creek is asymmetrical in the examined section. Unfortunately, we did not have enough borehole data in the upper and middle sections of the catchment to be able to examine the creek along a section. According to the data, in the M-7 borehole deepened to the north of the catchment, the lower rhyolite tuff was crossed at $\sim 63 \mathrm{~m}$, while in the borehole Nya-1, which was deepened within the catchment, it was crossed at $381 \mathrm{~m}$. There is no direct evidence for the structural nature of the stream at this upper section. However, on the basis of morphology, its preformation cannot be ruled out.

In the boreholes deepened on the valley bottom of the southern section of the Kulcsárvölgy Creek and on the top of its eastern interfluve, the position of the Pannonian sediments reveals significant structural movements. The floor level of the Nagyalföld Variegated Clay Formation is located at $\sim 63 \mathrm{~m}$ in the Em-71 borehole deepened on the western interfluve, while it is at $\sim 51 \mathrm{~m}$ in the Em-17 borehole on the valley bottom. In the Em-70 borehole deepened on the eastern interfluve of the creek, this level is located at $\sim 112 \mathrm{~m}$. These differences indicate the downfaulting of the valley and the uplift of its eastern interfluve, which confirms the structural preformation of the valley of Kulcsárvölgy Creek. The uplift of this eastern interfluve hill is also proved by the floor level of the Bükkalja Lignit Formation. This level was reached at $\sim 93 \mathrm{~m}$ in the Em-70 borehole, but in the H-5 borehole deepened in the Csincse Valley, it was found at -24 m. It is likely that this movement forced the Kulcsárvölgy and Nyék Creeks to merge. Based on these, we proved the preformation of the lower section of the Nyék Creek.

The position of the Pannonian sediments refutes the structural preformation of the section of the Csincse Creek south of the tuff strip. However, the valley asymmetry here points to a special situation. In the H-5 borehole deepened in the valley of Csincse Creek, the foot of the Nagyalföld Variegated Clay Formation is located higher than in the adjacent $\mathrm{H}-2$ and $\mathrm{Bg}-2$ boreholes. It is likely that the fault zone running in the Csincse Valley may have been active for a long period of time. We assume that before the deposition of the Nagyalföld Variegated Clay Formation, a narrowing lateral displacement took place in this area. As a result of this movement, the core of the zone emerged (Fig. 11 B). Presumably, the H-5 borehole was deepened into this upthrow block, which may explain the difference in elevation of floor level. After this uplift, a sedimentation phase took place again, which resulted in the formation of the Nagyalföld Variegated Clay Formation. Following the sedimentation, the fault zone reactivated, but probably with different kinematics. This structural element may have caused the preformation of the valley.

The valley of the Geszt Creek is also asymmetrical. In the $\mathrm{Bg}-4$ borehole deepened on the western interfluve hill of the stream, the floor of the Nagyalföld Variegated Clay Formation is located much higher than in the $\mathrm{Bg}-2$ borehole deepened at the valley floor. This significant difference cannot be explained by purely denudation. It was probably caused by tectonic movements; however, the proof of this hypothesis requires further investigations.

A

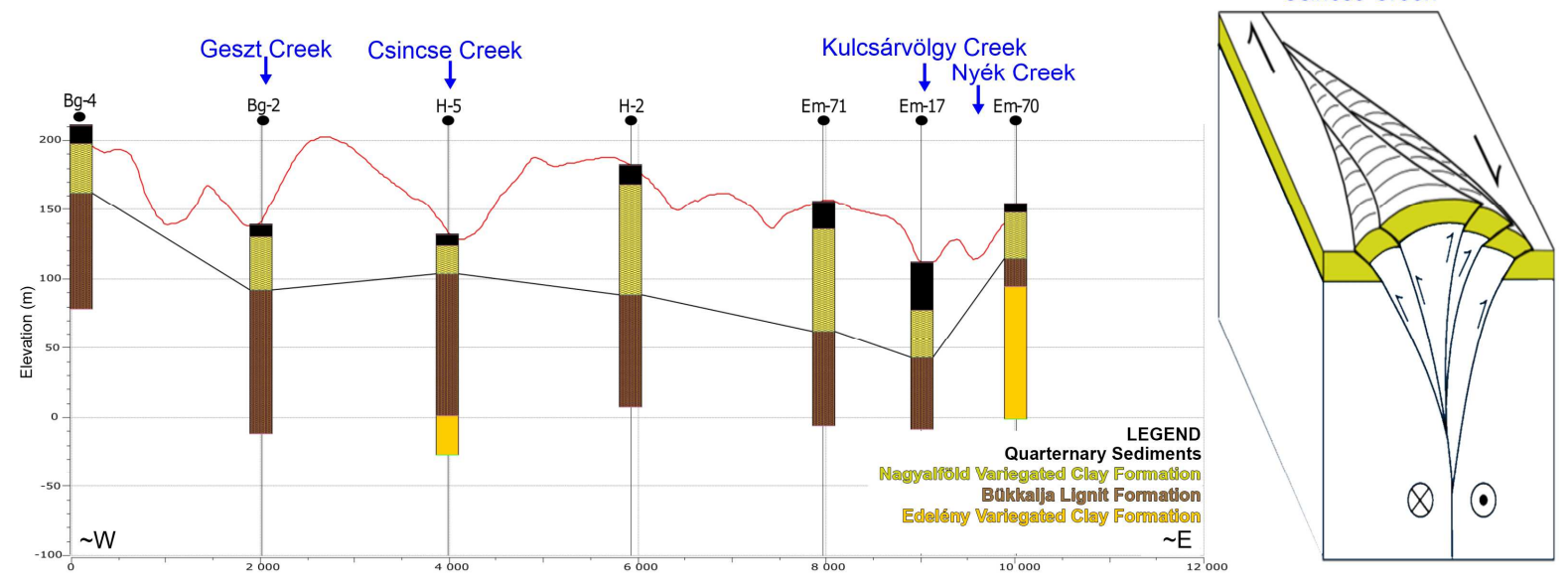

Distance $(m)$

Fig. 11. Cross-section of the borehole data (A), supposed reserve or positive flower structure in the Csincse Creek valley (B) (Twiss \& Moores, 1992). 


\section{Conclusion}

Based on swath profile analysis performed in the research area, the Kisgyör Basin can be interpreted as a structural basin. Its northern edge is bounded by a fault zone, separating the Southern-Bükk area from the Bükkalja. The southern edge of the basin is a structurally tilted escarpment (cuesta). The fault which caused this tilting can also be followed in the Tarizsa Valley, and we assume that this fault can be traced along the northern edge of the central-volcanic complex. The valley sections of Csincse, Kulcsárvölgy and Geszt Creeks leaving the volcanic strip are structurally preformed. It was proven by the existence of asymmetric valleys identified by the swath profile analysis and by the different elevations of areas covered by the welded ignimbrites of Tar Dacite Tuff Formation used as an indicator of tectonic movements.

We proved the existence of 4 hypothesised stream captures in the abandoned valleys of the Csincse Creek, the Tatar-árok, Geszt Creek and Csókás Valley. We also managed to identify a morphological level (rock terrace) along the Csincse Creek and Tatar-árok by swath profile analysis. The formation of these landforms can be explained by structural processes.

Based on our examinations, it can be concluded that the structural development of the region strongly influenced the formation of the landforms of the research area.

\section{References}

Burnak, D., \& Anderson, R. (2001). Tectonic geomorphology. - Blackwell Science, Malden.

Csontos, L. (1988). Geological study of a portion of the Internal Carpathians: the Bükk massif. [Étude géologique d'une portion des Carpathes Internes: le massif du Bükk] - PhD Thesis University of Lille I.

Csontos, L. (1999). Structural outline of the Bükk Mts. [N. Hungary]. [A Bükk hegység szerkezetének főbb vonásai]. Bulletin of the Hungarian Geological Society 129 (4). 611-651.

Csorba, P, Ádám, Sz., Bartos-Elekes, Zs., Bata, T., Bede-Fazekas, Á., Czúcz, B., Csima, P., Csüllög, G., Fodor, N., Frisnyák, S., Horváth, G., Illés, G., Kiss, G., Kocsis, K., Kollányi, L., Konkoly-Gyuró, É., Lepesi, N., Lóczy, D., Malatinszky, Á., Mezősi, G., Mikesy, G., Molnár, Zs., Pásztor, L., Somodi, I., Szegedi, S., Szilassi, P., Tamás, L., Tirászi, Á., \& Vasvári, M. (2018). Landscapes. In Kocsis, K. (Eds.), National Atlas of Hungary: Natural environment (pp. 112-129). Budapest. Hungarian Academy of Sciences Research Centre for Astronomy and Earth Sciences.

Dobos, A. (2002). Geomorphology of Bükkalja II. [A Bükkalja II. felszínalaktani leírás]. In Baráz Cs. (Eds.), A Bükki Nemzeti Park (pp. 217-228). Eger: Bükki Nemzeti Park Igazgatóság.

Fielding, E. J. (1996). Tibet uplift and erosion. Tectonophysics 260 (1-3), 55-84. https://doi.org/10.1016/0040-1951(96)00076-5

Gyalog, L., \& Síkhegyi, F. (2005). Geological map of Hungary (M-34-138, Miskolc) 1:100 000. (Eds.: Rónai, A., \& Less, Gy.). Hungarian Institute of Geology and Geophysics, Budapest.

Hevesi, A. (1978). Structural and landscape development of Bükk Mts. [A Bükk szerkezet- és felszínfejlődésének vázlata] Hungarian Geographical Bulletin 27 (2), 169-203.

Hevesi, A. (2002a). Geographical position, formation and climate of the Bükk Mts. [A Bükk hegység földrajzi helyzete, kialakulása, éghajlata] In Baráz Cs. (Eds.), A Bükki Nemzeti Park (pp. 15-22). Eger: Bükki Nemzeti Park Igazgatóság.

Hevesi, A. (2002b). Surface evolution II. Surface development. [Fejlődéstörténet II. Felszínfejlődés] In Baráz Cs. (Eds.), A Bükki Nemzeti Park (pp. 83-108). Eger: Bükki Nemzeti Park Igazgatóság.

Hevesi, A., \& Záhorszki, A. (2000). The results of the 1: 10000 geomorphological mapping of the MiskolcTapolca Kőmázsák and thier sorroundings so far. [A Miskolc-Tapolcai Kőmázsák és környékük 1: 10000 felszínalaktani térképezésének eddigi eredményei] Szombathely, Karsztfejlödés 5, 41-45.

Hevesi, A. (2003). Landscape classification of the Carpathian Basin and the Carpathians. [A Kárpát-medence és a Kárpátok természetföldrajzi tájtagolása] Hungarian Geographical Bulletin 52 (3-4), 253-267.

Keller, E. A., \& Pinter, N. (1996). Active Tectonics: Earthquakes, Uplift and Landforms. Prentice Hall, New Jersey, USA.

Korup, O. O., Schmidt, J., \& McSaveney, M. J. (2005). Regional relief characteristics and denudation pattern of the western Southern Alps, New Zealand. Geomorphology 71 (3-4), 402-423. https://doi.org/10.1016/j.geomorph.2005.04.013

Krolopp, E., Schweitzer, F., Scheuer, Gy., Hably, L., Skoflek, I., \& Kordos, L. (1989). Geomorphological, palaeohydrological and palaeontological investigation of the Pleistocene travertine of Eger. [Az egri pleisztocén édesvízi mészkő geomorfológiai, paleohidrológiai és őslénytani vizsgálata] Bulletin of the Hungarian Geological Society 119, 5-29. 
Kovács G. (2013). The relationship between neotectonics and surface evolution in the Eastern Foreland of the Alps. [Fiatal tektonika és felszínfejlődés kapcsolata az Alpok keleti előterében] PhD Thesis, ELTE Budapest.

Kühni, A., \& Pfiffner, O. I. (2001). The relief of the Swiss Alps and adjacent areas and its relation to lithology and structure: topographic analysis from a 250-m DEM. Geomorphology 41 (4), 285-307. https://doi.org/10.1016/S0169-555X(01)00060-5

Less, Gy., Kovács S., Pelikán, P., Pentelényi, L., \& Sásdi, L. (2005). Geology of the Bükk Mountains. Explanatory Book to the Geological Map of the Bükk Mountains (1:50 000).

Lukács, R., Harangi, Sz., Radócz, Gy., Kádár, M., Pécskay, Z., \& Ntaflos, T. (2010). The Miocene pyroclastic rocks of the boreholes Miskolc-7, Miskolc-8 and Nyékládháza-1 and their correlation with the ignimbrites of Bükkalja. [A Miskolc-7, Miskolc-8 és Nyékládháza-1 fúrások miocén vulkáni kőzetei és párhuzamosításuk a Bükkalja vulkáni képződményeivel]. Bulletin of the Hungarian Geological Society 140 (1), 31-48.

Lukács, R., Harangi, Sz., Guillong, M., Bachmann, O., Fodor, L., Buret, Y., Dunkl, I., Sliwinski, J., von Quadt, A., Peytcheva, I., \& Zimmerer, M. (2018). Early to Mid-Miocene syn-extensional massive silicic volcanism in the Pannonian Basin (East-Central Europe): Eruption chronology, correlation potential and

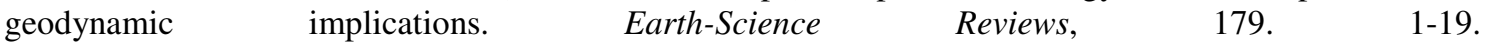
https://doi.org/10.1016/j.earscirev.2018.02.005

Németh, N. (2005). Structural geological conditions of the eastern part of South-Eastern Bükk. [A DélkeletiBükk keleti részének szerkezetföldtani viszonyai] $\mathrm{PhD}$ Thesis. University of Miskolc, Miskolc.

Pecsmány, P. (2017). DEM based morphometrical studies for the Bükkalja basins detection. [A Bükkalja medencéinek kimutatási digitális felszínmodellen végzett statisztikai vizsgálatokkal] PhD Forum, Miskolc. 57-67.

Pecsmány, P., \& Vágó, J. (2020). Relationship between deep structure and recent surface in the Bükkalja. [Mélyszerkezet és a domborzat közötti kapcsolat a Bükkalja területén] Müszaki Földtudományi Közlemények, 89 (1), 29-34.

Pentelényi, L. (2002). Bükkalja I. - Geological sketch. [A Bükkalja I. Földtani vázlat] In Baráz Cs. (Eds.), A Bükki Nemzeti Park (pp. 205-216). Eger: Bükki Nemzeti Park Igazgatóság.

Pentelényi, L. (2005). The Miocene pyroclastic assemblage of Bükkalja. [A bükkaljai miocén piroklasztikum összlet] In Pelikán, P. (Eds), A Bükk hegység földtana. Magyarázó a Bükk-hegység földtani térképéhez (1:50 000) (pp. 110-125). MÁFI, Budapest.

Petrik, A. (2016). Cenozoic Structural Evolution of the Southern Bükk Foreland. [A Bükk déli elöterének kainozoos szerkezetalakulása.] PhD Thesis. ELTE-TTK. Budapest.

Pinczés, Z. (1957). Geomorphological Problems of The Eger Valley. [Az Eger-völgy problémái] Hungarian Geographical Bulletin 6, 29-43.

Pinczés, Z., Martonné Erdős, K., \& Dobos, A. (1993). Differences and similarities in the Pleistocene surface evolution of foothill areas. [Eltérések és hasonlóságok a hegylábfelszínek pleisztocén felszínfejlődésében] Hungarian Geographical Review 117 (41) 3, 149-162.

Radócz, Gy. (1989). Exploratory drilling data from the SE foreland of the Bükk Mountains. - Manuscript. [Kutatófúrási adatok a Bükk hegység DK-I előteréből. - Kézírat]. Hungarian Geological, Mining and Geophysical Database, T.18834. 4. + 5 Figure.

Robl, J., Hergarten, S., \& Stüwe, K. (2008). Morphological analysis of the drainage system in the Eastern Alps. - Tectonophysics 460 (1-4), 263-277. https://doi.org/10.1016/j.tecto.2008.08.024

Stolar, D. B., Willett, S. D., \& Montgomery, D. R. (2007). Characterization of topographic steady state in Taiwan. - Earth and Planetary Science Letters 261 (3-4), 421-431. https://doi.org/10.1016/j.eps1.2007.07.045

Telbisz, T. (2009). Application of DEM analysis methods in geomorphological mapping of karst areas. [Digitális domborzatelemzési módszerek alkalmazása karsztos területek geomorfológiai térképezésében] HunDEM 2009 and GeoInfo 2009 Conference - Miskolc. 1-13.

Telbisz, T. (2011). Large-scale relief of the Slovak Karst and Aggtelek Karst (Gömör-Torna/Gemer-Turňa Karst) - a DEM-based study. - Hungarian Geographical Bulletin 60 (4), 379-396.

Telbisz, T., Kovács, G., \& Székely, B. (2011): Making swath profil and swath analysis. [Sávszelvények készítése és elemzése] HunDEM 2009 and GeoInfo 2009 Conference - Miskolc. 1-8.

Telbisz, T., Kovács, G., Székely, B., \& Szabó, J. (2013). Topographic swath profile analysis: a generalization and sensitivity evaluation of a digital terrain analysis tool. Zeitschrift für Geomorphologie 57 (1), $485-$ 513. https://doi.org/10.1127/0372-8854/2013/0110

Twiss, R. J. \& Moores, E. M. (1992): Structural Geology. W. H. Freeman \& Co., San Francisco.

Vágó, J., \& Hegedűs, A. (2011). DEM-based examination of pediment levels: a case study in Bükkalja, Hungary. Hungarian Geographical Bulletin 60. (1), 25-44. 
Vágó, J. (2012). The effects of rock quallity on the drainage network of Bükkalja. [A kőzetminőség szerepe a Bükkalja völgy- és vízhálózatának kialakulásában] PhD Thesis. University of Miskolc.

Zámolyi, A., Kovács, G., Székely, B., \& Timár, G (2010). A morphometric analysis of the fault pattern of the Bakony Mountains: Some tectonic geomorphological implications. [A Bakony vetőmintázatának morfometriai vizsgálata és az ebből levonható néhány tektonikus geomorfológiai következtetés] Bulletin of the Hungarian Geological Society. 104 (4), 439-453. 